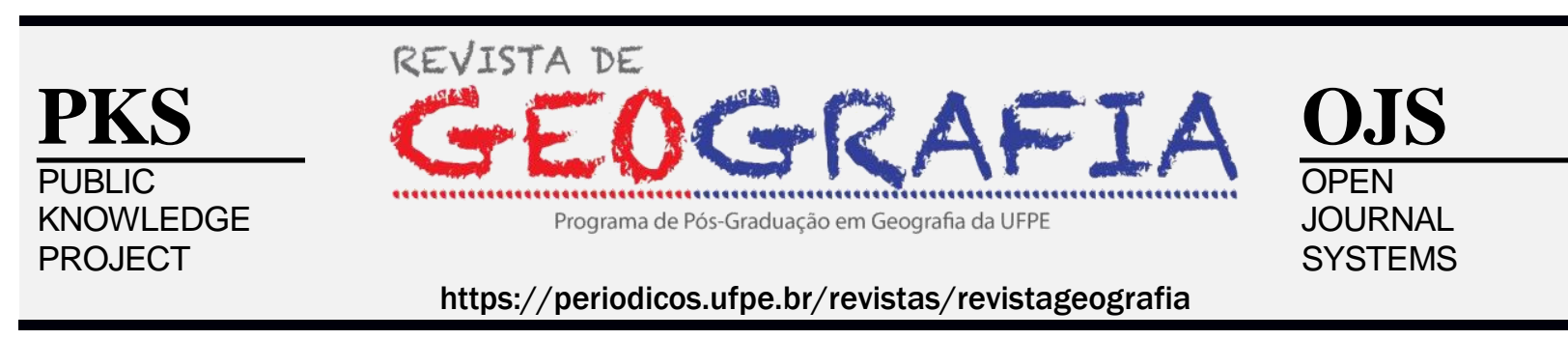

\title{
TRABALHO ESCRAVO CONTEMPORÂNEO E A ESPACIALIZAÇÃO DO CAPITAL
}

\author{
Sávio José Dias Rodrigues ${ }^{1}$, Francisco Amaro Gomes de Alencar ${ }^{2}$ \\ ${ }^{1}$ Universidade Federal do Maranhão, Coordenação de Estudos Africanos e Afro-Brasileiros, e-mail: \\ saviodiasbr@hotmail.com \\ ${ }^{2}$ Universidade Federal do Ceará (UFC), Departamento de Geografia; e-mail: famaro.ufc@gmail.com;
}

Artigo recebido em 24/02/17 e aceito em 23/01/18

\begin{abstract}
RESUMO
Análise da permanência do trabalho escravo a partir da dinâmica de espacialização do capital, relacionado a contradição entre modernidade e arcaico no seu desenvolvimento. Procedeu-se revisão bibliográfica, trabalhos de campo em municípios maranhenses, bem como busca em bancos de dados do IBGE, CPT, MTE. O Maranhão é o maior exportador de mão de obra resgatada de trabalho escravo contemporâneo. A partir do panorama de vulnerabilidade socioeconômica é possível perceber a posição de subalternidade deste espaço. A produção de espaços subalternos, e a existência de trabalhadores migrantes que se põe como mão de obra barata e disponível para o desenvolvimento do modo de produção é um elemento visível na contemporaneidade. Sendo assim, o trabalho escravo acaba por ser uma relação de exploração que não se torna oposta à modernidade, mas sim, como parte dela.
\end{abstract}

Palavras-chave: Trabalho escravo. Espacialização. Capital. Maranhão.

\section{SLAVERY CONTEMPORARY AND THE CAPITAL SPACIALIZATION}

\begin{abstract}
:
Analysis of the permanence of slave labor based on the dynamics of spatialisation of capital, related to the contradiction between modernity and archaic in its development. A bibliographical review was carried out, field work was carried out in Maranhão municipalities, as well as a search in databases of IBGE, CPT, MTE. Maranhão is the largest exporter of labor rescued from contemporary slave labor. From the perspective of socioeconomic vulnerability it is possible to perceive the subaltern position of this space. The production of subaltern spaces, and the existence of migrant workers that are put as cheap and available labor for the development of the mode of production is a visible element in the contemporaneity. Thus, slave labor turns out to be a relation of exploitation that does not become opposed to modernity, but rather as part of it.
\end{abstract}

Keywords: Slave labor. Space. Capital. Maranhão. 


\section{INTRODUÇÃO}

Onde homens valem menos que bois

Frase de entrada de entrevista da Revista Carta Capital com maranhense que foi escravizado ${ }^{1}$

É ele o escravo maldito,

O velho desamparado,

Bem como o cedro lascado,

Bem como o cedro no chão.

Tem por leito de agonias

As lájeas do pavimento,

E como único lamento

Passa rugindo o tufão.

Castro Alves, Antítese.

Castro Alves foi um poeta da primeira fase do romantismo brasileiro. Nasceu em 1867, no interior da Bahia, ele teve a sensibilidade de compreender o drama dos negros escravizados do seu tempo. Demonstrou seu protesto compondo versos que fizeram com que ele fosse conhecido como o "poeta dos escravos". Sua poesia de revolta e que mostrava a agonia do sofrimento da liberdade cercada, como do canto da mãe que nina o seu filho e diz da felicidade da araponga errante: "Que é livre, que livre voa/ Para as bandas do seu ninho/ E nas braúnas à tarde/ Canta longe do caminho".

A poesia de Castro Alves passa pelo sofrimento, eclode pela resistência de Palmares, símbolo da luta contra a escravidão. À luta do quilombo, ele dá um "Salve! Região dos valentes". Como abolicionista, talvez ele não tivesse ideia de que mais de 120 anos depois da abolição oficial da escravatura, seus versos se tornariam tão atuais, mas recitados de outra maneira, agora não mais da escravidão institucionalizada. A antítese do escravo maldito reflete o que o pesquisador Felipe Milanez (2011) escreve em reportagem da Carta Capital. Descreve a entrevista com um trabalhador maranhense que foi escravizado no Pará: "O maranhense João resolveu buscar trabalho no Pará, onde homens valem menos que bois". A escravidão faz com que o homem valha menos que um animal, como numa maldição designada aos que migram. Dois momentos da vida de João, o sujeito relatado na reportagem, foram descritas na frase e que mostra bem o que ele é: João migra, pois trabalhador, ele não

\footnotetext{
${ }^{1}$ Reportagem "Entrevista com um escravo: O maranhense João resolveu buscar trabalho no Pará, onde homens valem menos que bois" (MILANEZ, 2011).

Rodrigues e Alencar, $2019 \quad$ ISSN 0104-5490
} 
encontrou trabalho em seu estado de origem. Ele foi escravizado, e tratado como mercadoria, mais barata que o gado.

Porém, mesmo com situações como essas retratadas nesse tipo de reportagem, o trabalho escravo contemporâneo é um tema silenciado. Talvez porque a ocorrência desse tipo de situação indicasse que o propalado progresso e desenvolvimento como sinônimos de bemestar social não fosse uma realidade no contexto do modo de produção.

Por isso, nesse artigo pretendemos analisar a permanência do uso do trabalho escravo contemporâneo a partir da dinâmica do capital no Brasil, refletir sobre a contradição entre o desenvolvimento do modo de produção e a reprodução e uso da exploração do trabalho a partir da imobilização de força de trabalho. Dessa maneira, compreendemos o trabalho escravo contemporâneo através das condições de existência e reprodução do modo de produção capitalista com sua vinculação com a produção de capital a partir da acumulação primitiva.

Esse artigo é parte das reflexões da tese de doutoramento em geografia, pela Universidade Federal do Ceará, que se intitula "Quem não tem é escravo de quem tem: Migração camponesa e a reprodução do trabalho escravo contemporâneo", defendida em 2016 (RODRIGUES, 2016). Como tal, apesar de termos feito muitos trabalhos de campo em municípios do estado, aqui eles não ficam evidentes. Optamos por não colocar as entrevistas, nem trechos, por ser uma parcela da reflexão contida na tese.

Nas últimas três décadas, o Brasil vem experimentando um surto de modernização que, além de ser associado como sinônimo de desenvolvimento é fortemente relacionado às técnicas e as inovações científicas, trazendo a tônica do debate da agricultura, bem como as relações de trabalho que vêm assimilando essas condições e a substituição dos trabalhadores pelo trabalho acumulado das máquinas. Por exemplo, o trabalho no corte da cana-de-açúcar tem sofrido implicações oriundas da inserção de maquinário nessa atividade e são divulgadas como uma das maneiras de modernizar essa atividade. Outro exemplo são as condições de trabalho no plantio da soja que estão relacionadas também com a possibilidade de incremento técnico.

Nesse contexto, trabalho escravo contemporâneo é não somente uma contradição do sistema, mas, também a negação do modelo de trabalhador que é estigmatizado pelo capitalismo. Ele passa a ser a evidência radical do uso de outras maneiras de trabalho na obtenção de capital no capitalismo. Como parte da expansão do capitalismo no campo, ele 
também apresenta propriedades que demonstram que seu desenvolvimento é multivariado e que não segue apenas um caminho, mas vários para alcançar os objetivos da acumulação.

\section{O TRABALHO ESCRAVO CONTEMPORÂNEO NO BRASIL: ENTRE RELATOS E APROPRIAÇÕES CONCEITUAIS}

Foi a pior situação pela qual passei na minha vida. A nossa condição era de animal, não de ser humano

Reginaldo Viana da Costa 26 anos, de Barras (PI), libertado na obra de uma escola em SP em $2014^{2}$

O livro de Caio Prado Júnior, "História Econômica do Brasil”, expõe como a formação econômica do país esteve ligada ao desenvolvimento do modo de produção capitalista, no cenário de rupturas de sistemas e estruturas que ele analisa. É interessante notar as resistências empreendidas pelas elites de cada período e ciclo econômico com a intenção de manter suas bases de dominação política. Uma dessas rupturas está ligada à abolição da escravidão no país, que foi até fortalecida com o tráfico de escravos, mas que em meados do século XIX mostra sinais de decomposição. Segundo Prado Júnior (1963), em 1831 foi apresentado um projeto ao Parlamento para a abolição da escravatura, mas a câmara se recusou a apreciar. Esse alvoroço em torno do projeto mostra o quanto era permissiva a sociedade brasileira em torno da degradação do outro, sendo até infundado pensar o contrário, não sendo os objetivos nem sequer considerados para deliberação.

Após a abolição da escravatura, mesmo de maneira ilegal, o trabalho escravo perdurou no Brasil. Os relatos sobre a permanência do trabalho escravo contemporâneo em várias atividades são encontrados na literatura e em diários publicados que retrataram a vida no século XX. Um exemplo é o texto de Euclides da Cunha (2006) “À margem da história”. Nele, o autor a partir de sua experiência na Amazônia no início do século XX, descreveu a situação dos nordestinos que migraram para a região Norte do país, atraídos pela atividade de retirada do látex das seringueiras. A partir desse movimento, Ricardo Rezende Figueira e Adonia Prado (2011, p. 11) comentam a obra de Euclides da Cunha, escrevendo que "[...] o nordestino empurrado pela necessidade para a região, era aguardado para '[...] a mais imperfeita organização do trabalho"” (CUNHA, 2006, p. 28). Estes autores citam o fato de

2 Reportagem do portal G1, “TRABALHO ESCRAVO EXISTE?”, disponível no site: http://g1.globo.com/economia/trabalho-escravo-2014/platb/

Rodrigues e Alencar, $2019 \quad$ ISSN 0104-5490


Euclides já revelar (ou ainda revelar) "[...] a existência de homens atados aos seringais, vítimas de um crime que não era aleatório, mas intencional” (2011, p. 11).

Tomado de maneira natural no período, esse relato de Euclides da Cunha, na verdade, retratava fatos que não se davam de maneira isolada e aconteciam de forma generalizada e acatados por grande parte da sociedade brasileira com naturalidade. Principalmente os seringais amazônicos eram espaços propícios dessas formas de exploração do trabalho humano. Trabalhadores eram tratados como animais e a distância de suas regiões de origem (o Nordeste, sobretudo) favorecia esse tipo de situação.

A restrição à liberdade desses trabalhadores tinha um percurso simples, segundo os autores, "a trama da prisão da pessoa constava inicialmente do adiantamento recebido para a viagem, o transporte, os gastos provenientes da compra de mercadorias e instrumentos de trabalho" (FIGUEIRA; PRADO, 2011, p. 11). Assim, se elaborava uma complexa rede de aliciamento e restrição da liberdade, sobretudo com a dívida contraída no ato do deslocamento do trabalhador, que o fazia em busca de melhores condições de vida, frente a uma estrutura fundiária e de acesso à terra na região Nordeste que os impulsionavam a migrar.

Ricardo Rezende Figueira e Adonia Prado (2011) citam ainda os relatos de Ferreira de Castro e Thomaz Davatz, afirmando que esses não tiveram a mesma sorte que Euclides, tendo vivenciado a experiência na sua forma mais cruel: foram escravizados. Ferreira de Castro saiu de Portugal para o Brasil e foi levado a Belém-PA, onde viveu quatro anos nas condições que Cunha descrevera em "Á margem da história". Castro acabou por escrever um romance inspirado nessa experiência que se chamou "A Selva". Thomaz Davatz escreveu o livro "Memórias de um Colono no Brasil" que é um memorial de sua história e de outros colonos nas fazendas de café de São Paulo. "Ali tinham sido submetidos não apenas à situação-limite da imigração em terra estrangeira, mas à condição de escravidão" (FIGUEIRA; PRADO, 2011, p. 13).

Da mesma maneira que para as situações presenciadas e caracterizadas por Euclides da Cunha, as situações de escravidão contemporânea seguem o mesmo desejo dos antigos escravagistas, a necessidade de acumulação de capital. Porém, os sujeitos envolvidos na limitação da liberdade dos trabalhadores já eram outros. "Era a pecuária que, financiada e incentivada pela ditadura, concentrava terra, aliciava e submetia os novos trabalhadores ao mecanismo do endividamento" (FIGUEIRA; PRADO, 2011, p. 13). Assim, durante o século $\mathrm{XX}$ a região amazônica se tornou o lugar de destino principalmente de nordestinos e que sob as novas formas de exploração econômica da região foram submetidos à superexploração e ao 
trabalho escravo contemporâneo, sendo que essas atividades foram largamente anunciadas como parte da ocupação da região norte e estruturados como estratégia geopolítica de integração nacional.

Apesar das mudanças no que diz respeito às atividades que escravizam, a lógica descrita por Euclides da Cunha permanecia, “[...] é o homem que trabalha para escravizar-se" (CUNHA, 2006).

Diferente do período descrito por Euclides da Cunha, o final do século XX e o início do século XXI, a pecuária, a abertura de fazendas, o corte da cana-de-açúcar, além de atividades tipicamente urbanas, como a construção civil fazem parte desse processo de limitação de liberdade no Brasil. Atividades que se tornaram símbolos da modernização do campo brasileiro também se beneficiaram de mecanismos de exploração do trabalhador baseado no trabalho escravo contemporâneo, sobretudo, no preparo da terra ou abertura da fazenda.

Relatos expressos por viajantes, romancistas e estudiosos nos ajudam a perceber que mesmo com a assinatura da "Lei Áurea" e o fim do regime de escravidão de maneira legal, a forma de exploração do trabalhador a partir da restrição da liberdade perdurou de maneira ilegal até o século XXI.

Quando Neide Esterci (2008) começa numa narrativa a descrever a cena de um trabalhador que desce o rio em cima de uma canoa sob a mira das armas de dois homens, fazendo o leitor se sentir fora do seu tempo, traz, na verdade, o fato de que isso acontecia corriqueiramente no cotidiano das regiões rurais do país durante o século XX, mas que era camuflada.

Um primeiro obstáculo foi a própria designação do trabalho escravo. Termos como "trabalho análogo ao escravo", "trabalho escravo moderno", ou "trabalho escravo contemporâneo" têm sido utilizados. A opção de José de Souza Martins (1997, p. 72) por não seguir a tentativa de classificação prévia, é por ele entender que o fenômeno se dá numa “complexa e contraditória teia de conexões que lhes dá vida e sentido". Assim, o contexto do fenômeno pode lhe conferir uma série de variações fazendo fugir a tal definição, mas isso, apesar de dar possibilidades de ampliar o entendimento do fenômeno, dá pouco significado ao combate da prática ilegal. Assim, a não definição abre caminhos para a fragilização do combate ao trabalho escravo.

Dentro da literatura existem referências a vários conceitos de trabalho escravo e muitas vezes há a opção por assimilar outras designações para se referir a um mesmo 
processo, como por exemplo, "escravidão contemporânea" ou "moderna", ou ainda da própria legislação que adota o termo "trabalho análogo à escravidão".

Como escreve Neide Esterci (2008, p. 04) “As classificações se fazem de acordo com o contexto, os critérios e as posições dos diversos atores envolvidos ou que se pronunciam em cada caso". Não só a designação em si, mas o próprio enquadramento das situações e os vários critérios utilizados, mas o que tem preponderado é o contexto e as posições dos diversos atores envolvidos. Esses termos, muitas vezes, não conseguem abranger as situações de humilhação, castigos físicos e morais, torturas e muitas vezes a morte, já que a limitação conceitual se dá na sua forma de representação do real que não consegue abarcar sua maneira de operar no mundo. Assim, a utilização de referências pode ser importante quando se trata do entendimento de um conceito. Nesse caso, Neide Esterci (2008) faz uma análise da utilização desses vários termos do ponto de vista da dominação e dos dois sujeitos principais envolvidos, o escravo e o escravagista. Para ela:

Do ponto de vista conceitual, pode-se tratar as situações referidas como escravidão, servidão ou trabalho escravo como relações de dominação. Mas, falar em dominação pressupõe que algum tipo de legitimação seja atribuída ao dominante, tanto por parte dos dominados quanto de outros setores da sociedade. A legitimação se expressa em atitudes de consentimento, e está condicionada a um esforço constante dos dominadores no sentido de obter consentimento dos dominados (ESTERCI, 2008, p. 5).

Entendemos que essa legitimação se dá principalmente pelo aspecto econômico, em que o dominador detém o poder de vida de outrem pela propriedade dos meios de subsistência. A dominação que se dá pelo poder econômico, em relação aos pobres que não tem acesso à renda, emprego, terras, e a própria subsistência, se apresenta como uma concessão de dádivas por parte dos proprietários. Estes têm o poder de decisão de quem vive e quem morre de fome, e se concedem o direito à vida é por se apresentarem como caridosos.

Teresa Sales (1994), ao discutir as "raízes da desigualdade social na cultura política brasileira" escreve sobre essa relação de submissão que o pobre tem em relação aos "poderosos". Para ela:

[...] a pobreza do brasileiro não é um estado que tem a ver apenas com suas condições econômicas. Ela tem a ver igualmente com sua condição de submissão política e social. E o compromisso coronelista é que está por trás desse tipo de autojustificação da pobreza como sendo do interesse dos 'grandes' do local, como o meio mais importante de eles obterem os favores necessários ao moto-contínuo de seu mando e de sua riqueza. A vinculação pobreza-submissão, mais que uma marca da cultura política herdada do monopólio do mando pelo domínio territorial, é uma marca desse estado de compromisso herdado da nossa República Velha (SALES, 1994, p. s/d). 
A legitimação da dominação no trabalho escravo contemporâneo tem sido também um dos elementos da sua conceitualização. Na verdade, sua definição é difícil, pois se apresenta como uma situação anacrônica para a sociedade atual, como um resquício que carrega uma série de representações, que até dificultam sua apreensão como uma violência à dignidade humana. Comumente se associa à escravidão a coerção da liberdade pela violência, implicando na imagem das correntes e da vigilância armada. Porém, as formas de coerção do trabalhador ultrapassam essa maneira direta de limitar sua liberdade. A lógica de opressão e de poder sobre a liberdade do ser humano ultrapassa a corrente, ela pode ser exercida sem armas, submetendo os trabalhadores ao poder pela necessidade do sujeito buscar sua sobrevivência. A pobreza é o mote desta forma de subordinação. O trabalhador pobre que necessita de condições de vida que podem ser dadas pelo proprietário dos meios de produção. Assim, como no Fausto de Goethe, para o pobre, o mesmo que cria as condições de pobreza e mostrando que a eles pode também trazer a morte, aparece como aquele que lhe dá a vida.

A bibliografia que busca analisar o trabalho escravo contemporâneo a partir das situações de restrição da liberdade tem apontado para um padrão em comum, a dívida como mecanismo de coerção do sujeito e de sua liberdade de ir e vir (FIGUEIRA, 2004; ESTERCI, 2008; MOURA, 2009, SAKAMOTO, 2011). A dívida tem servido aos escravagistas não somente pela retenção do trabalhador e de seus ganhos para o seu pagamento, a partir da via da ameaça, mas também como elemento moral de restrição da liberdade, em que o trabalhador se sente obrigado a pagar uma dívida. A honra do devedor move o seu desejo de quitação, mesmo tendo a consciência da impossibilidade disso acontecer (ESTERCI, 2008).

Entendemos da mesma forma que Antônio Alves Almeida (2011), ao considerar que não é apenas uma discussão semântica. É acima disso, um debate em torno dos problemas causados por essa prática em termos de dignidade para os sujeitos envolvidos e escravizados e para a sociedade em geral. É importante ressaltar que essa multiplicidade de termos indica que os critérios de análise estão sendo construídos e como afirma o mesmo autor, os termos "estão em discussão tanto no campo político-ideológico quanto no que diz respeito ao seu enquadramento na legislação trabalhista e nos códigos de defesa dos direitos humanos" (ALMEIDA, 2011, p. 176). Esse debate traz consigo uma carga ideológica capaz de mobilizar ou não a sociedade, bem como os aparelhos de mídia e de justiça.

A discussão que se travou em torno da aprovação da Proposta de Emenda à Constituição (PEC) no 57A/1999 e 438/2001 (da Câmara dos Deputados) que trata da expropriação e destinação para a reforma agrária de propriedades rurais e urbanas que sejam 
flagradas com o cultivo ilegal de plantas psicotrópicas ou a exploração de trabalho escravo foi um demonstrativo da importância que há em torno da designação e do que poderia ser enquadrado como trabalho escravo contemporâneo.

Atualmente, a designação na legislação do que seja trabalho escravo contemporâneo está contida no Código Penal Brasileiro, que define como a redução de alguém a condição análoga à de escravo, submetendo-o a trabalhos forçados ou a jornada exaustiva, ou ainda o sujeitando a condições degradantes de trabalho, também pode ser restringindo, por qualquer meio, sua locomoção em razão de dívida contraída com o empregador ou preposto (BRASIL, 1940). Porém, apoiados principalmente pela elite agropecuária e do agronegócio, esse conceito tem sido criticado por alguns segmentos do Congresso Nacional como sendo muito amplo e assim, um empecilho para os setores do agronegócio, que se dizem os porta-vozes do desenvolvimento nacional. Em matéria publicada no portal G1, Felipe Néri (2014) cita o relator da proposta da PEC 54/13, o senador Romero Jucá (PMDB-RR), que avaliou que a definição de trabalho escravo é muito vaga, devendo ser mais clara. Para o senador, "Precisamos definir o que é uma jornada exaustiva e o que é um trabalho degradante, que pode mudar de um estado pro outro [...]". Ele justifica a partir de diferenças regionais em relação ao trabalho ou descanso, em que, segundo ele "Em São Paulo, por exemplo, um trabalhador pode achar degradante trabalhar sem ar-condicionado e sem água. No Amazonas, tem trabalhador que trabalha precisando dormir em rede”. Essa crítica feita pelos setores do agronegócio e empunhadas pela bancada ruralista do Congresso pode ser lida como uma justificativa para a mudança nas medidas legislativas e dessa maneira, estratégia de fragilização do combate ao trabalho escravo contemporâneo, diminuindo o raio de abrangência do teor da lei.

A PEC do trabalho escravo foi aprovada após consenso de que a definição de trabalho escravo permanecesse a que estava contida no código penal, até que fosse regulamentada nova legislação que tratasse do tema de maneira específica. Posteriormente se voltaria a esse debate, a partir de uma proposta de regulamentação, que até já tramita no senado (PROJETO DE LEI DO SENADO N 432/2013).

Esse debate em torno do trabalho escravo ultrapassa os limites das designações e enquadramentos legais, sendo alvo dos discursos enquanto forma estratégica de fragilizar no seio da sociedade a repulsa moral à forma de exploração dos trabalhadores por maneiras de sub-humanas. O fortalecimento do combate ao trabalho escravo, nas últimas décadas, tem se dado principalmente pelas denúncias apuradas pelo MTE e pela CPT, porém, esbarra no 
discurso criado pela classe patronal, principalmente baseado em erros de interpretação da lei. $\mathrm{Na}$ verdade, o discurso da classe patronal tem negado a existência do trabalho escravo contemporâneo no país, e que seria uma equivocada leitura da legislação por parte da fiscalização. A alegação principal é que se trata de violações das leis trabalhistas e não do código penal.

A análise que Regina Bruno (2008) faz sobre esses discursos traz os argumentos utilizados pela classe patronal para se isentar das condenações, levando em conta o código penal, ou da culpa no uso de mão de obra a partir de exploração de força de trabalho degradante. Na verdade, ela faz sua análise a partir do uso dos transgênicos e do trabalho escravo na agropecuária por parte de segmentos patronais, no que ela chama de novas conflituosidades. Um primeiro argumento explica que o trabalho escravo é de fato um trabalho degradante e fruto de um Estado ineficiente. Transferir a culpa para o Estado do uso de mão de obra escrava é uma estratégia de assumir um papel de vítima frente as suas funções no desenvolvimento do Brasil. Os empregadores se apresentam como indivíduos salvadores da pátria e que não podem ser punidos por trazerem o progresso ao país, como se fossem vítimas de um processo exógeno às suas atividades. A utilização desse tipo de mão de obra é só resultado do seu papel frente ao desenvolvimento brasileiro e a ineficiência do Estado em promover este desenvolvimento, sendo assim, segundo esse discurso, eles seriam vítimas dessa ineficácia.

A transferência de responsabilidade em relação ao fato praticado, pondo o Estado como responsável pela escravidão contemporânea, segue um segundo argumento, de relativização do problema. Nesse argumento, o trabalho escravo só existe como fato isolado na sociedade brasileira. Isso nega os dados do Ministério do Trabalho e Emprego (MTE) e da Comissão Pastoral da Terra (CPT), que apontam uma permanência de números elevados em todas as regiões do país, desde as fronteiras consolidadas da agropecuária ou até as fronteiras em expansão. Também em áreas rurais ou em áreas urbanas. Em diversos ramos de atividades econômicas, esses números apontam que não se trata de fato isolado, mas sim de algo estrutural a esse modelo de desenvolvimento. Os dados da CPT de 2013 em relação ao trabalho escravo por atividade econômica são elucidadores nesse sentido. Nesses dados, podemos ver diversas atividades, tanto as que são geralmente associadas aos espaços urbanos como as que estão localizadas em espaços rurais (Ver tabela 1) 
Tabela 1: Total de incluídos na lista suja por ramo de atividade, Brasil - 2013

\begin{tabular}{llllllc}
\hline TIPO DE ATIVIDADE & \multicolumn{2}{l}{ Empregadores } & \multicolumn{2}{l}{ Libertados } & & \multicolumn{2}{l}{ Incluídos em 2013 } \\
\hline & Valor & $\%$ & Valor & $\%$ & Valor & $\%$ \\
& Absoluto & & Absoluto & & Absoluto \\
DESMATAMENTO & 27 & 4,7 & 499 & 4,1 & 3 & 2,8 \\
PECUÁRIA & 241 & 41,6 & 4.457 & 36,7 & 41 & 38,0 \\
REFLORESTAMENTO & 30 & 5,2 & 277 & 2,3 & 6 & 5,6 \\
EXTRATIVISMO & 15 & 2,6 & 108 & 0,9 & 1 & 0,9 \\
CANA & 23 & 4,0 & 2.751 & 22,6 & 5 & 4,6 \\
LAVOURA & 77 & 13,3 & 1.639 & 13,5 & 11 & 10,2 \\
CARVÃO & 96 & 16,6 & 1.266 & 10,4 & 26 & 24,1 \\
MINERAÇÃO & 13 & 2,2 & 142 & 1,2 & 3 & 2,8 \\
CONSTRUÇÃO & 24 & 4,1 & 621 & 5,1 & 5 & 4,6 \\
CONFECÇÃO & 4 & 0,7 & 29 & 0,2 & 3 & 2,8 \\
OUTRO & 29 & 5 & 357 & 2,9 & 4 & 108 \\
TOTAL & 579 & & 12.146 & & $, 3,7$
\end{tabular}

Fonte: Comissão Pastoral da Terra (2013)

Na tabela anterior, podemos constatar a participação da confecção e da construção civil, sendo que estas são atividades recentes a terem participação no trabalho escravo.

É preciso admitir que o uso dos conceitos, ou sua apropriação pelos entes do Estado tem um cunho ideológico, ao que István Mészáros (2008, p. 163) afirma ser a ilusão jurídica. Para ele:

é uma ilusão não porque afirma o impacto das ideias legais sobre os processos materiais, mas porque o faz ignorando as mediações materiais necessárias que tornam esse impacto totalmente possível. As leis não emanam simplesmente da "vontade livre dos indivíduos", mas do processo total da vida e das realidades institucionais do desenvolvimento social-dinâmico, dos quais as determinações volitivas dos indivíduos são parte integrante.

Em outras palavras, as leis têm classe, e isso tem sido enfático no combate ao trabalho escravo contemporâneo, no qual mais recentemente tem eclodido no congresso o debate que prega a supressão do termo trabalho degradante do artigo 149 do Código Penal, sendo este o que mais tem ocasionado condenações aos escravagistas. A vontade expressa nas leis segue um cunho ideológico e de manutenção do status quo das classes hegemônicas. A garantia de reprodução da estrutura vigente de poder, que se liga a reprodução do capital, já que poder político e poder econômico não podem ser pensados separados. Esse debate em torno da relação entre poder político e poder econômico é exemplificado por Teresa Sales (1994) já mencionada anteriormente. 
Assim, o trabalho escravo contemporâneo como prática e como designação na legislação que abrange o território brasileiro é uma situação de classe. Sua importância tem a ver com a luta de classes que perpassa as formas de exploração dos trabalhadores na produção capitalista. A disputa em torno da legislação vigente que trata do trabalho escravo contemporâneo é uma condição do conflito para a tomada da hegemonia a que Antonio Gramsci (1982) faz menção. É, em parte, forma de manutenção de status e de estruturas de poder econômico que se relaciona com a manutenção da ordem política dominada pelas elites que se dão no âmbito econômico.

O trabalho escravo contemporâneo adentra nesse contexto como parte da manutenção política e econômica das estruturas de poder vigentes. Ele é resultado, mas também causa da reprodução das elites, se tornando uma constância na história econômica do país.

\section{A PERMANÊNCIA DO TRABALHO ESCRAVO CONTEMPORÂNEO NO BRASIL}

Dizem que acabou a escravidão

Mas pra mim não

Mas pra mim não

Mas pra mim não

Mas pra mim não

João do Vale, Pra mim não ${ }^{3}$.

A coerção do trabalhador, da sua liberdade através de vários elementos, como o poder econômico, imposição moral ou psicológica, a relação entre empregador e trabalhador, ou mesmo a violência direta é o que tem sido mais utilizado para caracterizar o trabalho escravo contemporâneo. Esse tipo de violência, por um lado, se caracteriza pelo cerceamento da liberdade do sujeito, pela imposição indireta, que se dá pela sensação que o trabalhador tem de não poder sair ou se desvencilhar do seu empregador. De outro, pela imposição de violência física direta, através da utilização da força física e até da utilização de armas para evitar fugas de trabalhadores.

O trabalho escravo contemporâneo no país tem seguido um caminho que às vezes repete situações do passado, como o sequestro dos trabalhadores, mas ganha novas características como sequestro mediante alguma forma de aliciamento com mecanismos de subordinação do indivíduo, seja a partir da dívida, ou mesmo, a necessidade mediante a pobreza da pessoa. Apesar de não ser tal qual a propriedade legal do sujeito como na

${ }^{3}$ João do Vale. Disco "O Poeta do Povo". Gravadora Philips, 1965.

Rodrigues e Alencar, 2019 ISSN 0104-5490 
escravidão do período colonial/imperial, a propriedade do indivíduo na escravidão contemporânea tem objetivos próximos à manutenção da propriedade capitalista. Assim, o paralelo entre as duas formas de escravidão se dá não pela legalidade, mas sim, por sua função no modo de produção capitalista, ou seja, na forma da acumulação.

Ao escrever sobre os envolvidos escravagistas na prática do trabalho escravo, José Damião de Lima Trindade (2011), expõe sobre as formas que tem tomado no mundo:

Seja mediante a retomada do sequestro antigo e direto (África), seja pelo confinamento de trabalhadores migrantes reduzidos ao trabalho forçado por 'dívidas' impagáveis (Amazônia, Ásia), seja pela submissão de crianças e mulheres extremamente pobres (zonas rurais da América Latina e da Ásia), seja, ainda, pela submissão 'voluntária' de estrangeiros em situação irregular (grandes cidades da América Latina, da Ásia, até da Europa ocidental), relações de trabalho abertamente escravas ou a elas análogas voltam a ser adotadas em várias regiões, não importa quantos solenes tratados internacionais hajam proibido o trabalho não-livre (TRINDADE, 2011, p. 28).

O trabalho escravo tem sido utilizado como parte do processo de desenvolvimento do modo de produção. O uso do trabalho escravo parece estar perfeitamente adaptado ao desenvolvimento capitalista, apesar de suas contradições. A imobilização de força de trabalho tem seguido uma temporalidade que faz com que o escravagista não tenha problemas na manutenção física dessa força de trabalho. Ao mesmo tempo, ele não se confunde com ramos da produção modernos, em que o uso de mão de obra assalariada e com qualificação técnica é apropriada. Essa adaptação vem se mostrando com a permanência da utilização desta prática no país, mas também com sua transformação, sobretudo no que diz respeito às formas de imobilização da força de trabalho pelos escravagistas. Os números do Ministério do Trabalho e Emprego e da Comissão Pastoral da Terra demonstram que o trabalho escravo é uma realidade concreta atual no país.

A ilustração 1, mostra que de forma geral houve um crescimento no número de operações das equipes de fiscalização até 2013, o que pode estar relacionado com um maior número de estabelecimentos fiscalizados. 
Ilustração 1: Estabelecimentos e Operações de Fiscalização para Erradicação do Trabalho Escravo, Brasil - 1995 a 2013

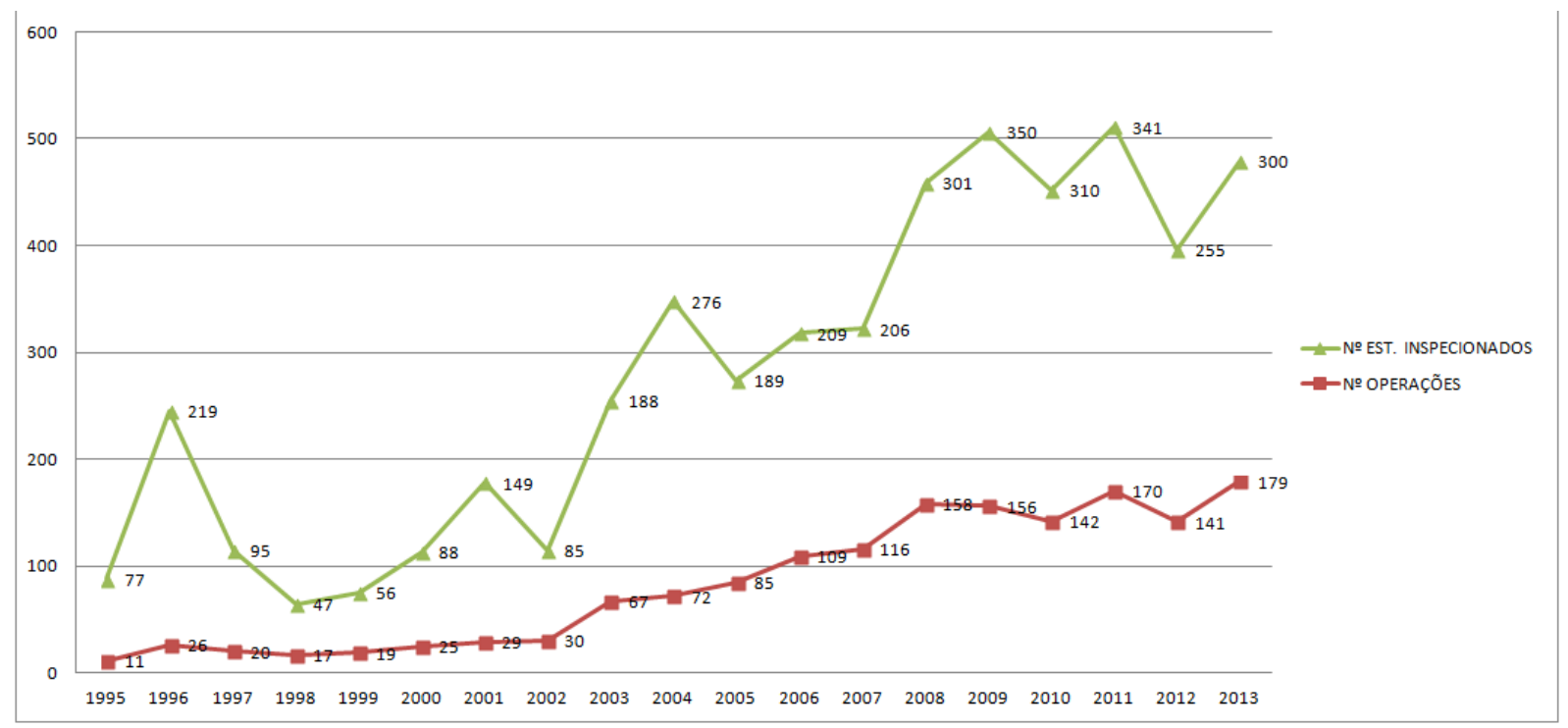

Fonte: Divisão de Fiscalização para Erradicação do Trabalho Escravo - DETRAE

Apesar de ter um acréscimo no número de operações de 1995 para 1996, que passou de 11 para 26, desse ano até 1998 houve um decréscimo e caiu para apenas 17 operações. A partir do ano de 1999, o número de ações de fiscalização cresceu gradativamente, tendo um salto de 2002, com 30 operações, para 2003, com 67. Um aumento de mais de $100 \%$, que pode ser relacionado à mudança de governo. Após esse ano, houve um período de crescimento no número de operações, com alguns anos tendo pequenas oscilações. Em 2013 houveram 179 ações registradas, um número relativamente grande se pensarmos que no início das operações foram realizadas apenas 11. Porém, se relacionarmos esse número com o tamanho do país e a quantidade de denúncias, esse número passa a ser bem pequeno.

A tendência foi uma maior atuação do MTE a partir de suas divisões específicas para erradicação do trabalho escravo ${ }^{4}$, impulsionados principalmente pela série de denúncias que Sindicatos de Trabalhadores Rurais e Comissão Pastoral da Terra fizeram nos últimos anos. Apesar de que nem toda denúncia ocasionou operação de fiscalização, muitas vezes pelo difícil acesso aos locais de onde ela partiu, outras vezes pelo lobby do denunciado que dificultou ações das equipes de fiscalização, o que acabou por incidir em dados extremos, com diferentes números apresentados pela CPT e pelo MTE da ocorrência de Trabalho

\footnotetext{
${ }^{4}$ A fiscalização é realizada através do Ministério do Trabalho e Emprego pela Divisão de Fiscalização para Erradicação do Trabalho Escravo e através do Grupo Especial de Fiscalização Móvel da Secretaria de Inspeção do Trabalho.
} 
Escravo no Brasil. Isso nos leva a supor que muitos dos casos de trabalho escravo não foram nem denunciados, muitas vezes pela violência que o escravagista impõe ou as condições precárias de acesso. As ameaças são constantes e acontecem de maneira transparente, como um dos casos mais recentes, de um fazendeiro que ameaçou um Padre da Diocese de Grajaú, no sul do Maranhão, por ter sido denunciado por este religioso de utilizar mão de obra escrava em sua propriedade ${ }^{5}$. A ameaça física, como no caso do padre, passa a ser corriqueira, sobretudo, nos redutos das oligarquias ${ }^{6}$ locais onde esse poder é mais evidente. Ricardo Rezende Figueira (2000) expõe que mesmo com os "novos tempos de "liberdade sindical", no Norte, os "velhos coronéis" continuam atuando. Sua conclusão se dá a partir da constatação da permanência do trabalho escravo contemporâneo em redutos escondidos do território brasileiro. Porém, não somente nesses lugares distantes dos grandes e médios centros, mas também próximos a grandes cidades, como é o exemplo do juiz da comarca de João Lisboa, próxima a cidade de Imperatriz, segundo maior município do Estado do Maranhão, em que o juiz Marcelo Baldochi foi flagrado por duas vezes com mão de obra escrava em suas propriedades. Também os casos de escravidão contemporânea nas carvoarias do município de Açailândia, como relatados no trabalho de Fagno da Silva Soares (2012) são exemplos.

A utilização de trabalho escravo por vários setores não ocorre apenas por que os trabalhadores desconhecessem seus direitos, mas, sobretudo, pelo fato de que os donos dos grandes imóveis aprenderam como burlar as leis. E mesmo quando alcançados pela legislação que proibia a utilização de mão de obra escrava, as multas e pagamentos muitas vezes eram pequenos em comparação ao benefício econômico do escravagista (FIGUEIRA, 2000).

O Atlas do Trabalho Escravo no Brasil, organizado pela Organização Não Governamental "Amigos da Terra: Amazônia brasileira” dá uma visão geral sobre os números do trabalho escravo no Brasil entre os anos de 1996 a 2006.

\footnotetext{
5 Portal "Vias de Fato": "Padre Marcos é ameaçado por fazendeiro por denunciar trabalho escravo em Grajaú do Maranhão". Disponível em: http://www.viasdefato.jor.br/index2/; Acesso em: 18/11/2014.

${ }^{6} \mathrm{O}$ trabalho de Cláudio Gonçalves Couto (2012) considera a utilização em três situações para o termo oligarquia, um primeiro como forma de designar grupos políticos tradicionais que dominam determinadas regiões; um segundo, como a acepção clássica que considera como sendo um "governo dos ricos" ou "grupo dos ricos"; a terceira situação que o termo é utilizado, considera como "como um grupo minoritário dotado de grande poder dentro de organizações, principalmente (mas não só) as de caráter representativo, ou o seu governo" (2012, p. 50). A utilização que fazemos desse termo, apesar de ser genérica e sem objetivos analíticos, considera que esses grupos operam em determinadas regiões se utilizando da reprodução da pobreza e da exploração do trabalho na produção da riqueza em que estão assentadas as classes dominantes. 
Ilustração 2: Trabalhadores Escravizados, Brasil - 1996 a 2006

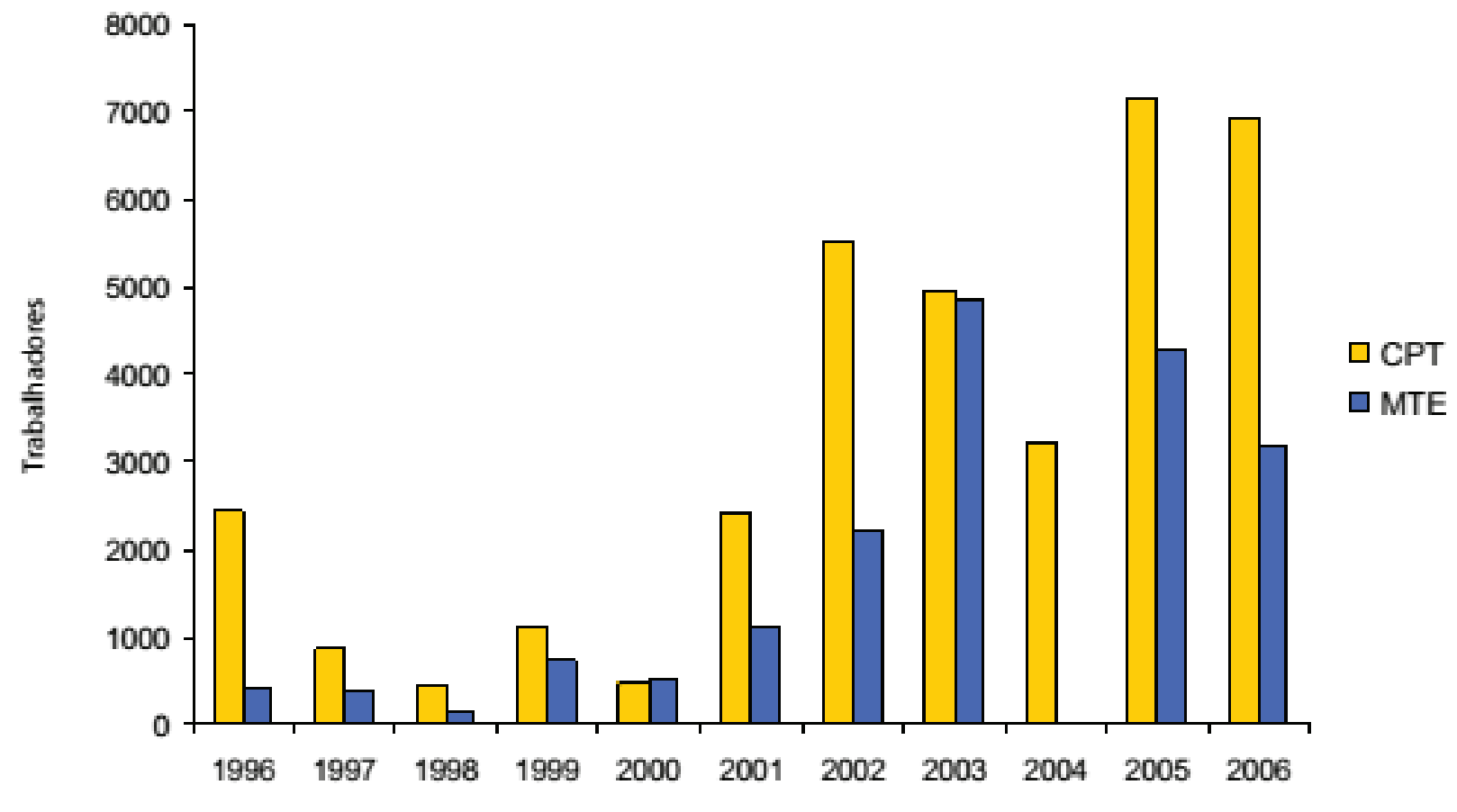

Fonte: Théry (2009).

Apesar do desencontro entre os dois bancos de dados, os números mostram uma tendência crescente no período de 1996 a 2006. Num primeiro momento, entre 1996 a 2000 ocorreu uma queda no número de trabalhadores escravizados, e, a partir de 2000 até 2003 aconteceu um crescimento exponencial. Segundo dados da CPT, saltou de 600 para aproximadamente 5.500 trabalhadores escravizados num intervalo de quatro anos. Essas oscilações para baixo ou para cima estão relacionadas a vários fatores como: avanço do agronegócio em áreas de fronteira, sobretudo com o avanço da cana-de-açúcar pelo centrooeste, a pecuária bovina e a soja na Amazônia são representativos do processo de expansão que podem ser citados aqui. Bem como, as denúncias da CPT, atuação do MTE através das delegacias regionais e de departamentos especializados desse ministério e o apoio da Polícia Federal também podem ser explicativas dessas oscilações.

Posterior a esse período, segundo compilação da CPT, os números de resgatados do trabalho escravo pelo MTE teve uma tendência de queda, como mostra o gráfico a seguir (Ilustração 3): 
Ilustração 3: Trabalhadores Resgatados, Brasil - 2006 a 2012

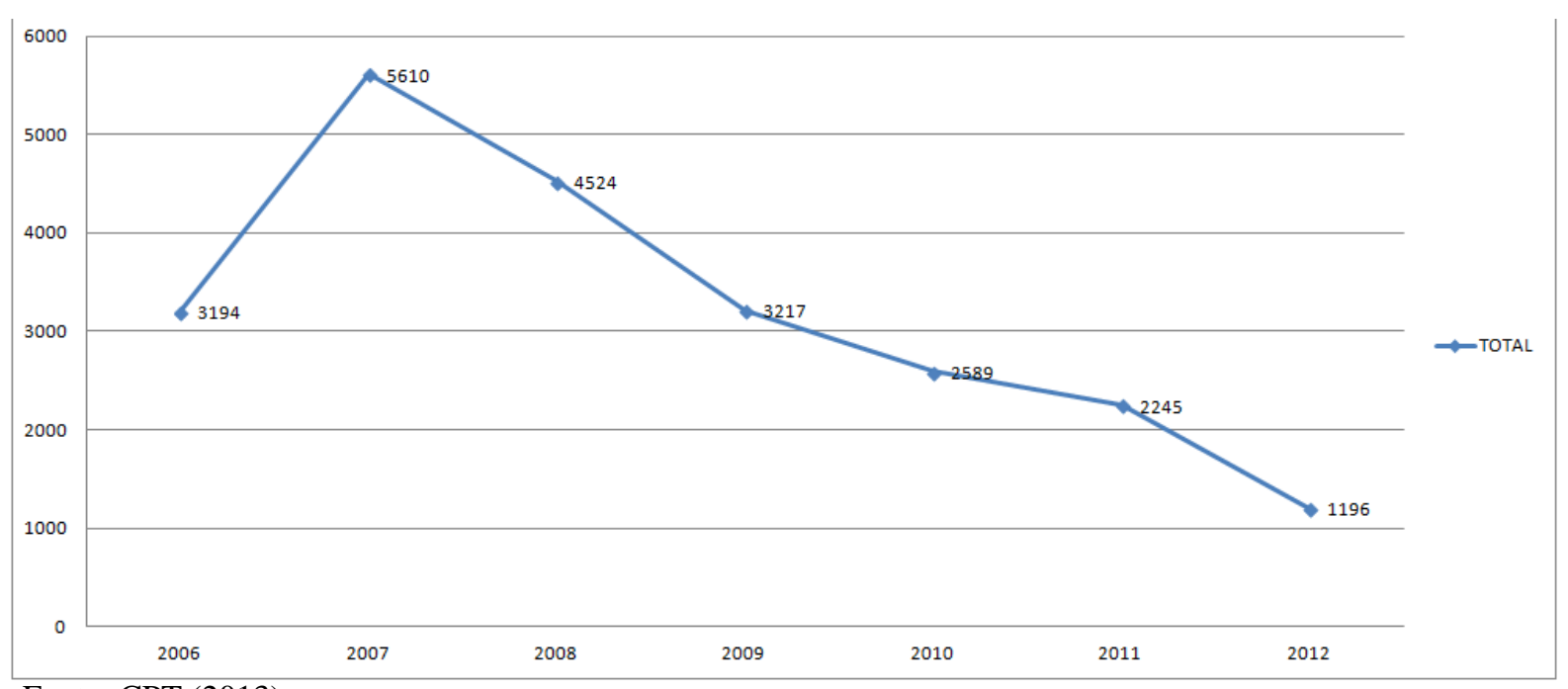

Fonte: CPT (2013).

No período de 2006 a 2012, houve uma queda gradativa nos números de trabalhadores resgatados, passou de 3.194 resgatados para 1.196. Nesse intervalo, houve um pico no ano de 2007 com 5.610 trabalhadores resgatados. Os dados mostram que no ano de 2013 já houve um crescimento em relação ao ano de 2012, sendo 2.208 pessoas resgatadas de situação de trabalho escravo. Esses números mostram apenas parte do problema, já que houve um grande número de trabalhadores que não foram alcançados pelas fiscalizações. "Há uma quantidade enorme de fiscalizações que não são feitas. E, nos rincões, as fiscalizações não chegam. Apesar de o número de libertados ser expressivo, ele ainda não mostra a realidade do trabalho escravo no Brasil", afirma Elizabete Flores, da CPT, em entrevista ao portal de notícias $\mathrm{G1}^{7}$. Em outra reportagem, José Guerra, coordenador da Comissão Nacional para a Erradicação do Trabalho Escravo (CONATRAE), ao comentar a diminuição do número de trabalhadores resgatados em relação a anos anteriores, afirma que "[...] estamos em uma encruzilhada. Não sabemos se o trabalho escravo está diminuindo ou está se tornando mais sofisticado. O que temos é um número menor de trabalhadores resgatados. Temos que pensar o que é isso" ". A modernização da prática do trabalho escravo contemporâneo pode ser uma das causas do declínio do número de resgatados. Essa modernização está atrelada à precarização do trabalho em atividades do agronegócio, mas também à utilização do trabalho escravo em atividades urbanas, como na construção civil ou na indústria. Assim, essas situações de sofisticação apresentadas na última reportagem podem ser apresentadas como

\footnotetext{
${ }^{7}$ Portal de notícias G1 - ECONOMIA: "Brasil registra 46 mil trabalhadores libertados em condição de escravos"

${ }^{8}$ Portal de notícias EBC - Agência Brasil: "Número de trabalhadores escravos resgatados diminui, diz comissão".
} 
parte de determinados setores da economia capitalista que o trabalho não qualificado pode ser utilizado.

Grande parte dos empregadores (ou empreendimentos) estão vinculados à pecuária, representando $41,6 \%$ do total de nomes que estavam na "lista suja do trabalho escravo" no ano de 2013. Além dessa atividade, também apresentam números bem representativos a produção de carvão $(16,6 \%)$ e a lavoura (13,3\%). A pecuária também liderou o número de trabalhadores libertados, com 36,7\% (4.457 trabalhadores resgatados), seguida pela cana-de-açúcar, com 22,6\% do total de libertados registrados na lista suja. A lavoura teve $13,5 \%$ e a carvoaria teve $10,4 \%$ do total de libertados. A inclusão de nomes na lista no ano de 2013 seguiu a mesma lógica, tendo a pecuária o maior número de inscritos, com 41 inclusos, sendo $38 \%$ do total. Foram inscritos, também, 26 nomes ligados a carvoaria (24,1\% do total) e 11 nomes com vinculação na atividade da lavoura.

Uma parte considerável dos resgatados foram escravizados no que chamamos de espaços de expansão do modo de produção capitalistas, onde a acumulação primitiva acontece de maneira mais candente. Nessas regiões de expansão, a utilização de tecnologia é menos frequente, principalmente pelo ônus que causaria aos empreendimentos.

José Damião de L. Trindade (2011) chama a atenção para o que ele designa de "franjas tecnológicas" do capitalismo. Essas, que entendemos serem regiões limites da acumulação, onde não é viável tecnicamente ou ainda por necessitar de um alto investimento de capital, não há a utilização de aparatos técnico-científicos nas atividades. Sendo assim, a utilização de mão de obra técnica e com formação qualificada se torna dispensável. Para o autor,

Nas franjas tecnológicas do capitalismo, onde quer que o trabalho braçal nãoqualificado ainda possa mostrar-se 'atraente' a empresários, diversas modalidades 'invisíveis' de escravidão retomam fôlego, nutrindo-se do desemprego massivo, da desvalorização da força de trabalho e da omissão/conivência hipócrita das elites economicamente dominantes (TRINDADE, 2011, p. 28).

Ponderamos que o trabalho escravo segue a necessidade do capitalismo de se reproduzir como modo de produção dinâmico, sendo assim, as evidências empíricas nos fazem crer que não é somente nas "franjas tecnológicas", apesar de, em primeiro momento, esse raciocínio ser convidativo. Os casos de trabalho escravo envolvendo empresas de tecnologia ${ }^{9}$ de ponta mostram que não é apenas nessa suposta "franja", como dito por Trindade (2011). Apesar de que nessas regiões, parece que pelo fato de haver maior

\footnotetext{
${ }^{9}$ Portal Olhar Digital: "Executivos declaram que Apple sabe do trabalho escravo nas fábricas da Foxconn"; Portal Bol Notícias: Câmera escondida revela abuso contra empregados em fabricante da Apple na China; Portal InPacto: "Chinês morre em fábrica da Apple após jornada excessiva de trabalho". 
dificuldade de acesso para a fiscalização e de ser mais distante das lentes da mídia nacional, a utilização do trabalho escravo contemporâneo ser mais frequente. As denúncias dessa prática em empresas de tecnologia, citado anteriormente, como também o trabalho escravo mascarado de trabalho precarizado são algumas das evidências mais gerais de que o trabalho escravo contemporâneo cada vez mais vem se tornando frequente nas cidades modernas e globalizadas e dentro dos circuitos dinâmicos da economia.

Mas também entendemos que a fronteira tem o papel de espaço-limite, entre o novo e o velho, entre as relações capitalistas e as relações não capitalistas, ou mesmo, como espaço de recriação e reinvenção do capital e aparece como principal região de incidência de trabalho escravo. Onde a subordinação das relações não capitalistas na produção de capital é um processo corriqueiro.

É preciso ressaltar que "há aspectos da escravidão colonial que permanecem na escravidão contemporânea, tais como: ameaças, violência, coerção física, punições exemplares, fugas e até assassinatos”, mas outras feições tomaram forma com a proibição do trabalho escravo. A dívida econômica é o principal instrumento dessa nova forma que o trabalho escravo toma na atualidade, "para agravar o quadro, na atualidade os escravos são tratados como devedores do patrão ou de seu respectivo representante - o gato - e são levados à submissão moral segundo a qual 'quem deve tem que pagar'” (ALMEIDA, 2011, p. 188). O autor continua afirmando que eles "passam a ser também escravos da sua consciência" (ALMEIDA, 2011, p. 188).

Figueira et al. (2011) chamam a atenção para a prática do "engodo", segundo eles:

Uma prática comum no aliciamento é o engodo - promessas de boas condições de remuneração e trabalho para atrair a vítima -, como afirmou um menor de idade libertado na [fazenda] São Roberto. Segundo ele, a proposta de pagamento foi de R\$ 200,00 e ao chegar à empreitada mudou para R \$ 100,00 (FIGUEIRA et al., 2011, p. 83).

As promessas de renda fácil, de ganhos fora dos padrões em suas regiões de origem são os principais atrativos no aliciamento. O aliciamento se dá, sobretudo, em regiões em que a população se encontra em situação de precariedade, com baixos índices sociais, dependência de programas de transferência de renda, limitação ao acesso aos meios de produção.

Isso abre oportunidade para que o escravagista se utilize de vários argumentos para a manutenção do trabalhador em situação de escravidão. Vários contextos fazem o trabalhador não poder se movimentar, a coerção do trabalhador através da dívida econômica, 
as distâncias e a precariedade do lugar onde se encontra, a própria violência que se dá pelo poder do escravagista, que pode ser uma violência física ou moral.

Um dos elementos ligados à escravidão contemporânea é a dificuldade de locomoção nos lugares onde os indivíduos são escravizados. Em grande parte, as regiões de maior ocorrência estão situadas na Amazônia oriental, que tem como característica as grandes distâncias entre as cidades, o que dificulta uma possível fuga dos trabalhadores. Isso tem sido utilizado como estratégia de imobilização do trabalhador sem necessariamente haver violência ou coerção física através de armas.

A distância da origem e local de naturalidade do trabalhador escravizado e da região de resgate é parte da evidência da migração como mobilizadora de mão de obra para atuar nas frentes de expansão e desenvolvimento capitalistas. Assim, o capitalismo atua mobilizando mão de obra na acumulação de força de trabalho da produção de capital. Esse processo é inerente ao modo de produção contemporâneo.

O fato dos resgatados estarem em outras regiões diferentes da sua origem se liga à condição de pobreza que esses trabalhadores estão inseridos e à saída em busca de trabalho e melhores condições. Para ilustrar, os dados de Índice de Desenvolvimento Humano (IDH) é um dos exemplos do processo de empobrecimento da população.

O estado do Maranhão, em 2008, mostrava o pior IDH da federação, com 0,683. O Pará apresentava nesse ano o $3^{\circ}$ pior índice da região norte, tendo um IDH de 0,755 (PNUD, 2008). Apesar de esses dados mostrarem uma situação de desenvolvimento baixo, são mascarados pelo IDH-Renda que tem uma influência significativa em decorrência das atividades agropecuárias e de extração mineral na região.

O mosaico na ilustração 5, retirado do Atlas do Trabalho Escravo no Brasil, demonstra as regiões de naturalidade do trabalhador escravizado (e seu domicílio), bem como onde estão localizadas as denúncias e onde foram resgatados. 
Ilustração 5: Mosaico de mapas espacializando naturalidade, domicílio, resgatados e denúncias de trabalho escravo, Brasil - 1996 a 2006
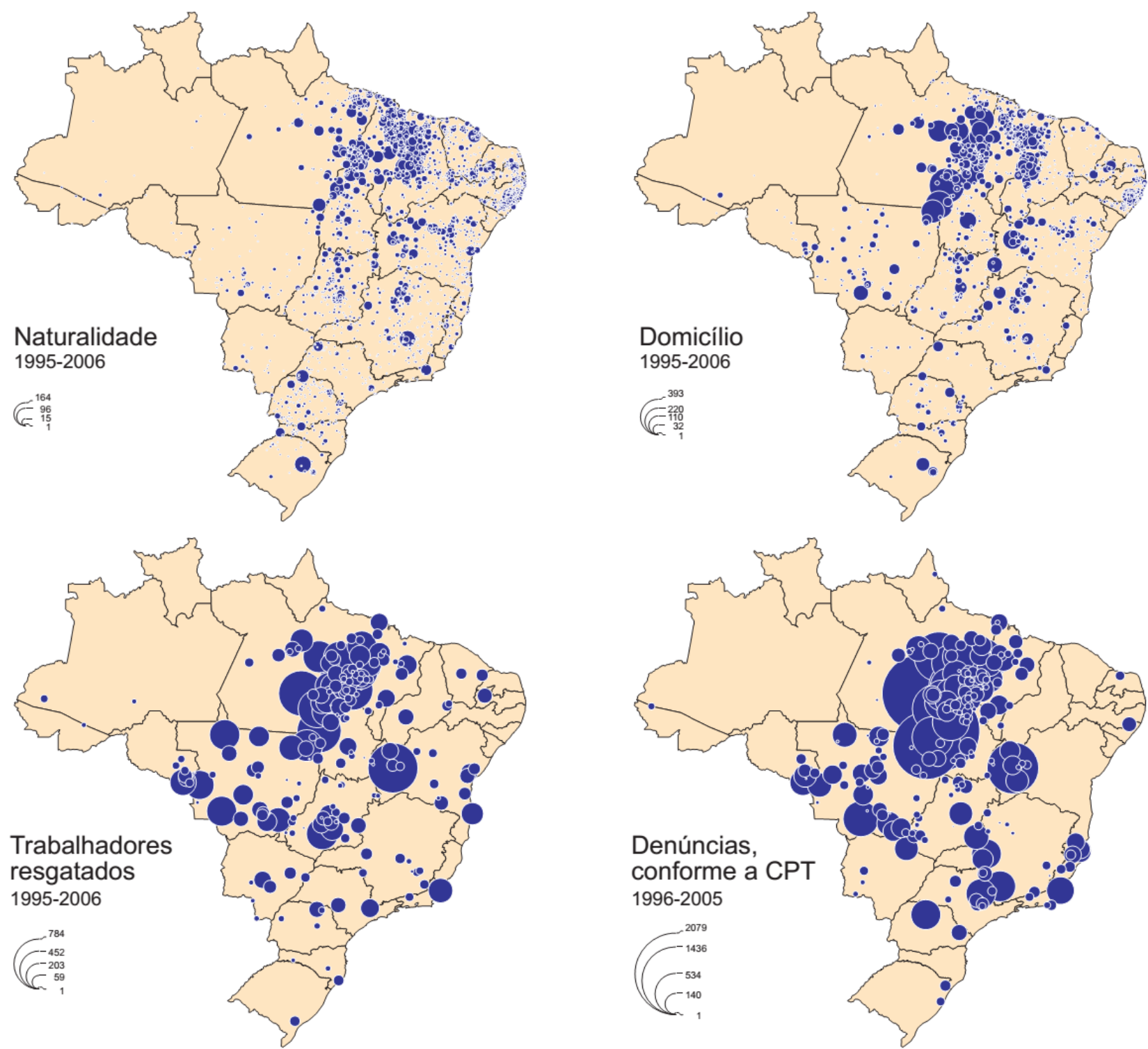

Fonte: MTE/SDTR, CPT

(C) EG,HT,JH,NAM-2007

Fonte: MTE/SDTR, CPT; Elaborado por Théry ET. All. (2009).

A naturalidade dos trabalhadores escravizados teve uma maior concentração no Maranhão, enquanto as denúncias se concentraram entre os Estados do Maranhão, Pará, Tocantins e Mato Grosso. O mosaico também mostra os lugares onde mais trabalhadores foram resgatados e Pará, Tocantins e Maranhão novamente despontaram. Com essa ilustração é perceptível que o trabalho escravo avança com força nas áreas de expansão da fronteira agropecuária, mas também tem sido utilizado com frequência em regiões de concentração urbana. 
A instituição do Cadastro de Empregadores que tenham submetido trabalhadores a condições análogas à de escravo (Portarias no 1.234/2003-MTE e 540/2004-MTE e substituídas pela Portaria Interministerial n 02/2011) significou um avanço no combate ao trabalho escravo no país e foi largamente utilizada pelos empregadores como uma justificativa para se colocarem como vítimas. A atualização semestral desse cadastro passou a ser chamada de "lista suja do trabalho escravo", que agrupa os nomes de empregadores flagrados na exploração de trabalhadores em condições análogas às de escravidão e condenados administrativamente pelas infrações do trabalho. Essa inclusão do nome dos empregadores flagrados com trabalhadores escravos têm sido alvo de várias ações que tentam retirar seus nomes, alegando a estigmatização contida no cadastro ${ }^{10}$.

Ao analisar algumas das ações que envolveram o cadastro e a tentativa de exclusão do nome do empregador da "lista suja", Daniel de Matos Sampaio Chagas (2007), faz uma síntese do posicionamento dos empregadores que "[...] quase sempre se apresentam como indivíduos produtivos e altruístas que empreendem seus negócios com vistas ao crescimento do país, gerando emprego e pagando impostos" (CHAGAS, 2007, p. 15). E o fato de cometerem "irregularidades trabalhistas", como se referem aos seus crimes, está dentro do cotidiano da atividade que praticam para alcançar os seus objetivos. Isso se dá pela naturalização da atrocidade, a barbárie passa a ser o cotidiano da exploração capitalista. $\mathrm{O}$ lucro como resultado, para esses sujeitos, justifica qualquer forma de exploração do trabalho.

\section{CAPITAL E TRABALHO ESCRAVO: A MODERNIDADE E O ARCAICO NO CAMPO BRASILEIRO}

Os casos de trabalho escravo contemporâneo não podem ser vistos como resquícios do passado que será suprimido pela modernização das atividades e pelo progresso, mas sim, são resultados do desenvolvimento das forças produtivas. A sua permanência diz muito mais respeito à dinâmica do capital e suas transformações, que não necessariamente substituem antigas relações, mas que as transforma adaptando-as a um novo ciclo capitalista.

10 Por decisão do Ministro do Supremo Tribunal Federal, Ricardo Lewandowski, em dezembro de 2014, a "lista suja" foi suspensa. A decisão foi por ordem da Ação Direta de Inconstitucionalidade (ADIN) no 5209 contra a Portaria Interministerial MTE/SDH n 2/2011 que criou o cadastro de empregadores flagrados com trabalho escravo. Porém, a partir da lei de acesso à informação, pôde-se gerar uma nova lista suja do trabalho escravo. Assim, em março de 2015, o MTE divulgou nova lista com os empregadores flagrados com trabalho escravo. Já em maio de 2016, o governo federal assinou nova portaria interministerial, que até o final de 2016 deve divulgar a lista dos empregadores flagrados.

Rodrigues e Alencar, $2019 \quad$ ISSN 0104-5490 
É importante notar que o processo de modernização brasileira acompanha a expansão das fronteiras no país. Esta é parte do movimento de expansão territorial do capital e tem um caráter de efetivação da reprodução do modo de produção a partir da criação de condições para a acumulação. A acumulação de capital ocorre num contexto espacial criando e recriando formas espaciais que são mobilizadas para este fim. A reestruturação do espaço impondo uma refuncionalização de suas estruturas faz parte deste processo. No Brasil, pode ser exemplificado com o processo de modernização das atividades agrícolas desde a década de 1970 nos cerrados brasileiros que passaram a cumprir um novo papel para a reprodução de capital com a produção de soja e posteriormente a produção de cana-de-açúcar.

As técnicas e as pesquisas científicas a serviço dos altos rendimentos na agropecuária, com o uso intensivo de máquinas nas lavouras, a inserção de tecnologias de ponta, como a utilização de chips de rastreamento na pecuária bovina e sistemas de posicionamento por satélite, dentre outras coisas fazem parte desse processo. Dessa maneira, a modernização da produção passa a ser utilizada como forma de recuperar os custos de capital empregado na produção a partir da diminuição do ciclo do capital e aplicando categorias da administração como eficiência e eficácia.

O que Marx (2011) explica acerca da mais valia que é produzida pelo investimento de certa quantia de capital, vem da junção da soma de dinheiro gasto com meios de produção, que se transforma em capital constante e a despendida com força de trabalho, que se torna capital variável. A vantagem de continuar ou mesmo elevar a taxa de mais-valia, mesmo quando se diminui a quantia gasta com meios de produção e com a força de trabalho, reside na disponibilização de capital a ser investido em outras atividades ou mesmo a possibilidade de modernização de outros ramos da produção.

A modernização da produção diminui o ciclo do capital, ao mesmo tempo em que aperfeiçoa o uso de força de trabalho na extração da mais-valia, aumentando as possibilidades de sua extração. Porém, “para funcionar o capital variável, é mister desembolsar capital constante em proporções adequadas, de acordo com a natureza técnica do processo de trabalho" (MARX, 2011, p. 252).

Assim, é importante a diferenciação do mesmo autor em relação à mais-valia absoluta e a mais-valia relativa. Para Marx (2013), os momentos simples do processo de trabalho são a atividade orientada a um fim, o seu objeto e o seu meio. Mas, nesse processo, há a produção de valor, a valorização do capital. Sob o capitalismo, há o consumo da força de trabalho pelo capitalista, revelando que: o trabalhador labora sob o domínio do capitalista, de 
quem pertence sua própria força de trabalho e o produto passa a ser também, propriedade do capitalista.

O valo da mercadoria, em Marx (2013), é determinado pela quantidade de trabalho materializada em seu valor de uso, pelo tempo de trabalho. Isso é o que se considera de mais-valia absoluta. Apesar de haver na obra de Marx, a ideia, também, de uma mais-valia relativa, que é vinculada a produtividade do trabalho, nos ocuparemos da mais-valia absoluta, sobretudo. Entendemos que o trabalho escravo é a colocação em prática da sua exploração, porém, um dado é colocado: não é a força de trabalho que é apropriada pelo capitalista, mas sim, também, o próprio corpo do trabalhador.

Dessa maneira, é a partir dessa análise que o uso do trabalho escravo contemporâneo tem a ver com a própria produção de capital, não estando fora dela.

Podemos dizer que a utilização de mão de obra escrava não é apenas um desvio de conduta do capitalista, já que a conjuntura natural não é de constante valorização do trabalhador. O capitalista procura circunstâncias para sua reprodução como tal e suas condições de exploração, potencializando a retirada de mais-valia a partir da diminuição do trabalho pago para o trabalhador e alargando o trabalho não pago.

Alessandra Gomes Mendes (2011, p. 96) considera dessa maneira:

A escravidão de trabalhadores como fenômeno persistente no Brasil compõe situações-limite inseridas num quadro mais amplo caracterizado pela precariedade nas relações de trabalho no conflito capital/trabalho e pelas condições de superexploração da força de trabalho.

As situações-limites podem ser estabelecidas como sendo aquelas em que o capital encontra obstáculos para acumulação, seja do ponto de vista espacial, seja em relação à disponibilidade de capital a ser investido. Nas situações em que o processo de modernização é lento, a necessidade de mobilização de capital a fim de manter permanente o incremento técnico faz com que a utilização de mão de obra em condições de superexploração seja uma das estratégias do capital.

O aprisionamento do trabalhador se dá com vistas a diminuir o tempo de trabalho pago e aumentar o que Marx (2013) chama de tempo de trabalho excedente. O seu aprisionamento se dá pelo que Otávio Guilherme Velho (1979) chama atenção, de a fronteira brasileira ter sido uma fronteira aberta, permitindo a reprodução camponesa em regiões livres. Assim sendo, o aprisionamento do trabalhador cumpre dois objetivos: manter a mão de obra necessária para a expansão dos empreendimentos; e não mobilizar capital para se transformar em capital variável. 
Em torno desse processo, de reprodução de uma relação dita arcaica no seio de reprodução do capital, podemos dizer que a modernidade se apropria do arcaico para sobreviver e se expandir. Em outras palavras, o desenvolvimento das forças produtivas necessita de relações não capitalistas para continuar sua expansão, sendo o arcaico, dessa maneira, parte do moderno. Assim, então, há uma imbricação da acumulação primitiva na reprodução ampliada do capital. Isso se dá em regiões ou situações de expansão e se torna uma ferramenta de capitalização e concorrência.

Há duas formas de acumulação de capital, uma através de sua reprodução, a outra pela acumulação primitiva. Esta é tida por Marx como uma acumulação anterior à acumulação capitalista, que não decorre do modo capitalista de produção, mas é seu ponto de partida. Para ele "a chamada acumulação primitiva é apenas o processo histórico que dissocia o trabalhador dos meios de produção" (MARX, 2013, p. 836). A dissociação acontece com o trabalhador sendo expropriado de diversas maneiras. Ele analisa essa separação a partir de vários processos, como o roubo dos bens da Igreja, a alienação fraudulenta dos domínios do Estado, transformação da propriedade feudal etc. Esses são vistos como métodos, na sua análise, da acumulação primitiva. Como base de todo o processo, "a expropriação do produtor rural, do camponês, que fica assim privado de suas terras [...]” (Idem, p. 838).

A separação do trabalhador de seus meios de produção, nesse caso, cria as condições de seu assalariamento. Constitui o trabalhador livre, que pode vender sua força de trabalho. Para Marx (2013), o trabalhador é livre de duas maneiras, primeiro, porque não é parte direta dos meios de produção e nem é proprietário destes. Porém, nesse caso, a acumulação primitiva assume o papel de se apropriar da liberdade do trabalhador, mantendo uma relação não-capitalista na obtenção da mais-valia e composição de capital. A segunda maneira, a partir do cerceamento da liberdade e apropriação da força de trabalho do trabalhador cria-se valor sob condições extremas de exploração.

A produção capitalista necessita de regiões não capitalistas para se desenvolver. A partir de sua natureza e de sua própria forma de existência não admite limitações nem mesmo em relação a utilização de formas não capitalistas de produzir capital. É uma condição histórica do capitalismo, não sendo apenas uma situação local. A função da acumulação primitiva é reproduzida nesses espaços, se imbricando nas situações de produção e contribuindo para a reprodução ampliada de capital. José de Sousa Martins nomeia essa pilhagem dentro do capitalismo como sendo reprodução anômala do capital (MARTINS, 1997). 
De um lado, as condições de reprodução do capital e a necessidade de mão de obra com disponibilidade de força de trabalho e de outro a necessidade de criação de condições que facilitem a sua disponibilização.

A acumulação capitalista se utiliza da reprodução da miséria para subsistir, e para driblar as crises. Ela se torna necessária para que relações não capitalistas subsistam dentro do modo de produção capitalista. Na verdade, a assimilação na estrutura do capital de elementos ditos arcaicos, como parte de sua reprodução é parte de sua condição de existência, nesse panorama de criação e recriação da miséria. Assim, visualizar situações contemporâneas similares a situações analisadas há mais de um século é uma constante. A recriação de bairros pobres, com uma segregação espacial dentro das cidades, analisada por Friedrich Engels (2008), mostra bem isso. A burguesia industrial inglesa do século XIX se reproduzia a partir de uma pobreza intensa e de bairros pobres próximos às fábricas, reservatórios de mão de obra barata que se submetia a toda forma de trabalho a baixo custo. O contexto de baixos salários e grande concentração de trabalhadores disponíveis nas cidades criou um ambiente propício para a expansão da indústria, mas, sobretudo, para uma alta exploração do trabalhador.

No caso brasileiro, a expropriação do trabalhador do campo, em que se separa o sujeito do meio de produção de sua subsistência, cria um exército de reserva capaz de suprir a expansão do capitalismo. Porém, a mobilização dessa força de trabalho se dá de maneira peculiar. Não é apenas a superexploração do trabalhador, mas sim, o próprio cerceamento e apropriação da sua força de trabalho, como numa recriação da acumulação primitiva, em que o trabalhador, visto como meio de produção é separado de sua liberdade com o intuito de criar as condições necessárias de produção de capital.

É importante chamar a atenção para o que João Antônio de Paula (2010) ressalta da relação entre crise econômica e reiteração do capitalismo dependente no Brasil. Para ele, há uma reiteração de "velhas políticas, travestidas de modernas e com cariz social, que no essencial confirmam a velha ordem social do capitalismo dependente, mediante a imposição de uma "novíssima dependência'[...]" (p. 37). Assim, mesmo os surtos de crescimento da economia brasileira não têm nada a ver com a saída do subdesenvolvimento. Isso é importante pois nos coloca na posição de refletir a economia brasileira dentro dos ciclos de modernização como parte do capitalismo dependente.

Podemos, a partir desse entendimento do capitalismo dependente no Brasil, pensar a acumulação primitiva que se dá para o desenvolvimento desse modo de produção. $\mathrm{O}$ que 
Carlos Brandão (2010, p. 41) chama de "Acumulação primitiva permanente" serve à reprodução do capitalismo no país. Para ele "Essas acumulações primitivas estariam baseadas na apropriabilidade privada extensiva/intensiva do território, na retenção especulativa da terra-propriedade e do dinheiro e na hegemonia da órbita da circulação no amplo espaço nacional” (Brandão, 2010, p.41).

Esse contexto é reconhecidamente parte do processo de acumulação, necessário e objetivo do modo de produção capitalista, que o mesmo autor chama de polimórfico. Ele admite que a acumulação primitiva não é uma fase passada, mas está contida no conceito de capital. Sua forma brasileira é parte do desenvolvimento desigual do modo de produção. Assim, ele expõe que "o caráter extensivo e predatório com que se desenhou a geografia desigual do desenvolvimento capitalista brasileiro determinou a apropriação contínua de porções territoriais em (re) estruturação nas frentes de expansão [...]” (idem, p. 51). Parte do processo de expropriação do capitalismo abrindo fronteiras, ou como na diferenciação feita por Harvey (2004), parte do processo de acumulação por espoliação.

David Harvey (2004) distingue a acumulação primitiva da acumulação por espoliação. A primeira cumpre o papel de abrir fronteiras para o modo de produção, disponibilizando terras e mão de obra. A segunda cumpre a função de expropriação de espaços já existentes, e cria oportunidades para o capitalismo.

A acumulação depende de vários fatores, dentre eles, as condições da força de trabalho e de sua exploração por parte do capitalista. A acumulação como força motriz do capital, segundo Harvey (2005) depende e tem como pressuposto três elementos. O primeiro, um excedente de mão de obra, que vai formar o exército industrial de reserva. Ele afirma assim:

[...] devem existir mecanismos para o aumento da oferta de força de trabalho, mediante, por exemplo, o estímulo ao crescimento populacional, a geração de correntes migratórias, a atração de 'elementos latentes' - força de trabalho empregada em situações não-capitalistas; mulheres, crianças etc. - para o trabalho, ou a criação de desemprego pelo uso de inovações que poupam trabalho (HARVEY, 2005, p. 44).

Nas franjas do sistema, dentro de situações-limites, o uso de relações não capitalistas, como a exploração do trabalho escravo se torna recorrente, sobretudo porque indica um dispêndio pequeno de capital. As correntes migratórias, de espaços subalternizados, disponibilizam mão de obra vulnerável ao aliciamento. Isso pode levar a outra reflexão, o capitalista precisa dessa mão de obra sã, em boas condições de trabalho, o que muitas vezes contradiz com as situações em que esses trabalhadores são encontrados. De certa forma, a 
legislação tem tido esse papel, de manter a mão de obra em condições de participar do processo produtivo, punindo essas atividades que transgridem o corpo do trabalhador para além do seu limite. Mas a sanidade, para o modo de produção, pode ser apenas um conceito relativo quando colocado pareado com as possibilidades de acumulação.

O segundo, a existência no mercado de quantidades necessárias de meios de produção (máquinas, matérias-primas, infraestrutura), que possibilitem a expansão da produção conforme o capital seja investido. Isso implica também, que haja uma relação recíproca entre quantidade de meios de produção e a capacidade técnica investida em cada ramo da produção. Porém, em ramos da produção em que a capacidade técnica é mínima, e a necessidade de mão de obra é maior, há a substituição da posse dos meios de produção pela posse da força de trabalho, como recurso para sanar a carência e a necessidade da perpetuidade da acumulação.

O terceiro elemento é um mercado para absorver quantidades crescentes de mercadorias, o que inicialmente se choca com o aprisionamento da força de trabalho que, não sendo livre, também não dispõe de liberdade para o consumo. A saída se dá com o fato de que a escravidão contemporânea, sobretudo a escravidão por dívida, é um recurso temporário. Mantém o trabalhador apenas por um período, sendo que a garantia de que o trabalhador retornará é a continuidade da dívida, que é artifício moral de retorno da mão de obra para o traficante.

Em cada um desses três elementos, a acumulação e seu progresso talvez encontre uma ou mais barreiras que ao serem atingidas, resultará numa crise. As crises são parte da estrutura de reprodução do capital. Expandir a partir de relações não capitalistas ameniza o efeito das crises no seu desenvolvimento. É importante perceber que as crises também têm um papel renovador no modo de produção. A capacidade criativa de encontrar saídas para as barreiras encontradas para a acumulação, seja do ponto de vista de disponibilidade de mercado, meios de produção, e força de trabalho, mostram uma ampla variedade de artifícios. David Harvey assim se refere: "Em geral, as crises periódicas devem ter o efeito de expandir capacidade produtiva e de renovar as condições de acumulação adicional. Podemos conceber cada crise como uma mudança do processo de acumulação para um nível novo e superior" (HARVEY, 2005, p. 47).

Num novo nível, o modo de produção apresentará, conforme esse autor algumas características, como, por exemplo, a produtividade da mão de obra aumentará pela utilização de máquinas e equipamentos mais sofisticados, sendo que os equipamentos antigos sofrerão 
um rebaixamento nos preços, uma desvalorização forçada. Outra característica que o autor se refere é a demanda efetiva expandida de produtos que esvaziará o mercado de todos os bens produzidos e o excedente de capital será atraído por novas linhas de produção, como, por exemplo, sob regulação do mercado, regiões oscilam entre o cultivo de cana-de-açúcar e de soja no Centro-Oeste brasileiro.

Ainda outra característica apresentada por Harvey (2005), mas que, a nosso ver, soa como consequência da crise é o custo da mão de obra que diminuirá devido o alto índice de desemprego. Isso acaba por ser fator de compensação para as baixas taxas de acumulação alcançadas pelos capitalistas em períodos de crise. O aumento da taxa de exploração do trabalhador para que não haja perdas por parte dos proprietários dos meios de produção.

Isso dá outra noção à acumulação em períodos de crise, que o capitalismo precisa se reinventar, abre o precedente do modo de produção se utilizar de outros modos de produção, e isso fica evidente na agricultura brasileira sendo tema já tratado por outros autores como José de Souza Martins (1997), Ariovaldo Umbelino de Oliveira (2002; 2005; 2006; 2007), dentre outros. A utilização de formas não capitalistas na reprodução ampliada do capital com o intuito de manter permanentes as taxas de acumulação se tornou ponto comum na literatura produzida no final do século XX, principalmente.

Porém, a utilização dessas formas coloca em conflito o próprio desenvolvimento do sistema. Se o modo de produção sobrevive com o pressuposto da apropriação da mais valia pelo capitalista, em que a separação do trabalhador do meio de produção é base do processo de apropriação e que tem na liberdade de venda de sua força de trabalho uma premissa básica, o uso de mão de obra escrava contemporânea se torna uma contradição. O aprisionamento do trabalhador é uma alternativa que diminui o custo da apropriação da força de trabalho, rebaixando o valor pago ao trabalhador como trabalho necessário. Assim, o modo de produção que se reproduz a partir de suas próprias contradições.

A dicotomia existente entre o arcaico ou "não moderno", como descrito por Horácio Antunes de Sant'Ana Júnior (2004) e a modernidade do mundo atual pode ser entendida dentro da perspectiva da relação entre várias escalas e não a exterioridade do modo de produção. Convencionou-se relacionar essa relação escalar dentro do âmbito do conflito, porém, desprezando que o global se faz no local e o local é parte do global como analisado por Anssi Paasi (2004) que faz uma análise das relações escalares dentro do conhecimento da realidade. A modernidade, dentro dessa relação de escalas, é tida como o global que se 
apresenta ao local num movimento hegemônico de subalternizar. O local, apenas o espaço da recepção da modernidade.

\section{CONSIDERAÇÕES FINAIS}

Num Brasil moderno, o uso de mão de obra escrava soa como um retorno ao passado. Um anacronismo no desenvolvimento econômico brasileiro. Porém, o uso do arcaico no processo de acumulação capitalista no Brasil tem que passar a ser entendido dentro do contexto do desenvolvimento do modo de produção no país, principalmente, a partir da modernização dos meios de produção e das relações de produção.

Este que parece um conflito entre a manutenção do arcaico e o desenvolvimento tecnológico no país, na verdade é uma contradição do modo de produção que se fez como característica peculiar do país, sobretudo da economia dependente, a partir da permanência de relações arcaicas de poder, nas quais a elite dominante se utilizava para não alterar seu status quo, como por exemplo, o domínio pela posse da terra em que se assentou o coronelismo.

$\mathrm{O}$ arcaico aparece, assim, como parte de uma estrutura de poder em que as oligarquias locais baseiam-se na propriedade da terra e nos interesses decorrentes, como por exemplo, a exploração de trabalhadores dependentes do poder econômico. Reforçando o argumento da permanência de relações não capitalistas na modernização brasileira.

A perpetuidade do arcaico, nesse sentido, e também a partir desse argumento, induz a pensar que se trata de uma situação temporária a ser suprimida pela modernização.

Essa maneira de se pensar acontecimentos ou espaços, que cotidianamente são interpretados como um desvio de conduta, como formas anômalas da modernidade, pode ser trazida na análise do trabalho escravo contemporâneo para o modo de produção capitalista. Ele não é anômalo, passa a não ser exceção na reprodução capitalista, mas sim, fazer parte da regra no processo de produção, reprodução do capital e acumulação capitalista.

Apesar de a reprodução capitalista não ser apenas baseada no trabalho escravo, atualmente necessita desta forma de exploração do trabalho, criando uma situação em que se monta uma cadeia produtiva de relações que se tornam indispensáveis ao ciclo do capital. Comércio, pequena produção, transporte, vários ramos da economia se tornam dependentes dos mecanismos de repressão da força de trabalho de maneira generalizada, mas principalmente nas regiões de fronteira e expansão das formas de reprodução do capital. 
Esse contexto cria uma estrutura de exploração em que a pobreza é um fio condutor e que liga o proprietário de terras a um sujeito que necessita de tudo para sobreviver, vendo no proprietário de terras seu redentor. Esta mesma pobreza cria um sujeito vulnerável, pois na procura de quem o salve, acha assim, os algozes de sua liberdade. O trabalho escravo não é a barbárie no contexto do de fora da civilização. Mas sim, a barbárie é condição da civilização nesse sentido. $\mathrm{O}$ trabalho escravo passa a ser a barbárie necessária do modo de produção capitalista.

\section{REFERÊNCIAS BIBLIOGRÁFICAS}

ALMEIDA, Antonio Alves. Trabalho escravo: a dignidade dilacerada pelo capital. In: FIGUEIRA, Ricardo Rezende; PRADO, Adonia Antunes (Orgs.) Olhares sobre a escravidão contemporânea: novas contribuições críticas. Cuiabá: EdUFMT, 2011.

BRANDÃO, Carlos. Acumulação primitiva permanente e desenvolvimento capitalista no Brasil contemporâneo. In: ALMEIDA, Alfredo Wagner Berno de (et al.). Capitalismo Globalizado e recursos naturais: fronteiras da acumulação no Brasil contemporâneo. Rio de Janeiro: Lamparina, 2010.

BRASIL. Código penal. Decreto-Lei $\mathrm{n}^{\circ}{ }_{2} 2.848$, de 7 de dezembro de 1940. Disponível em: http://www.planalto.gov.br/ccivil_03/decreto-lei/del2848.htm; Acesso em 19/12/2014

BRUNO, Regina. Agronegócio e novos modos de conflituosidade. In: FERNANDES, Bernardo Mançano (org.). Campesinato e agronegócio na América Latina: a questão agrária atual. São Paulo: Expressão Popular, 2008.

CHAGAS, Daniel de Matos Sampaio. O Ministério do Trabalho e Emprego e os subsídios para a defesa judicial da União nas ações relativas ao Cadastro de Empregadores do Trabalho Escravo. In: ORGANIZAÇÃO INTERNACIONAL DO TRABALHO. Possibilidades jurídicas de combate à escravidão contemporânea. Brasília: OIT, 2007.

COUTO, Cláudio Gonçalves. Oligarquia e processos de oligarquização: o aporte de michels à análise política contemporânea. In: REVISTA DE SOCIOLOGIA E POLÍTICA . v. 20, No 44: 47-62 NOV. 2012. 
CUNHA, Euclides da. À margem da História. São Paulo: Ed. Martin Claret, 2006.

ENGELS, Friedrich. A situação da classe trabalhadora na Inglaterra; tradução B. A. Schumann. São Paulo: Boitempo, 2008.

ESTERCI. Neide. Escravos da desigualdade: Um estudo dobre o uso repressivo da força de trabalho hoje. Rio de Janeiro: Centro Edelstein de Pesquisas Sociais, 2008.

ESTERCI. Neide. Escravos da desigualdade: Um estudo dobre o uso repressivo da força de trabalho hoje. Rio de Janeiro: Centro Edelstein de Pesquisas Sociais, 2008.

FIGUEIRA, Ricardo Rezende. Por que o trabalho escravo? ESTUDOS AVANÇADOS. n 14 (38), 2000.

FIGUEIRA, Ricardo Rezende; FREITAS, Adriana da Silva; MURAKAMI, Andrea Kazuko; CAVALIERI, Vera Lúcia. A escravidão contemporânea: relações existentes e estudo de caso. In: FIGUEIRA, Ricardo Rezende; PRADO, Adonia Antunes (Orgs.) Olhares sobre a escravidão contemporânea: novas contribuições críticas. Cuiabá: EdUFMT, 2011.

FIGUEIRA, Ricardo Rezende; PRADO, Adonia Antunes (Orgs.) Olhares sobre a escravidão contemporânea: novas contribuições críticas. Cuiabá: EdUFMT, 2011.

FIGUEIRA, Ricardo Rezende. Pisando fora da própria sombra: a escravidão por dívida no Brasil contemporâneo. Rio de Janeiro: Civilização Brasileira, 2004.

GRAMSCI, Antonio. Os intelectuais e a organização da cultura. 4.ed. Rio de Janeiro: Ed. Civilização Brasileira, 1982.

HARVEY, David. A Produção Capitalista do Espaço. Trad. Carla Szlak. São Paulo: Annablume, 2005. (Coleção: Geografia e Adjacências)

HARVEY, David. O novo imperialismo. São Paulo: Loyola, 2004.

MARTINS, José de Souza. Fronteira: A degradação do Outro nos confins do humano. São Paulo: HUCITEC, 1997. 
MARX, Karl. O Capital: crítica da economia política: livro I; Volume 1. $28^{\circ}$ Ed. Rio de Janeiro: Civilização Brasileira, 2011

MARX, Karl. O Capital: crítica da economia política: livro I; Volume 2. $26^{\circ}$ Ed. Rio de Janeiro: Civilização Brasileira, 2013.

MENDES, Alessandra Gomes. Trabalho escravo contemporâneo no Brasil: a denúncia como um dos caminhos na resistência dos trabalhadores à dominação. In: FIGUEIRA, Ricardo Rezende; PRADO, Adonia Antunes (Orgs.) Olhares sobre a escravidão contemporânea: novas contribuições críticas. Cuiabá: EdUFMT, 2011.

MÉSZÁROS, István. Filosofia, Ideologia e Ciência Social. São Paulo: Boitempo, 2008.

MILANEZ, Felipe. O maranhense João resolveu buscar trabalho no Pará, onde homens valem menos que bois. Carta Capital, 2011. Disponível em: http://www.cartacapital.com.br/sociedade/entrevista-com-um-escravo; acesso em: 18/08/2014

MOURA, Flávia de Almeida. Escravos da precisão: economia família e estratégias de sobrevivência de trabalhadores rurais em Codó (MA). São Luis: EUFMA, 2009.

NÉRI, Felipe. Congresso Nacional promulga a PEC do Trabalho Escravo: Emenda determina expropriação de terra onde houver trabalho escravo. Texto prevê desapropriação de propriedade usada para cultivo de drogas. Publicado em: 05/06/2014. Disponível em: http://g1.globo.com/politica/noticia/2014/06/congresso-nacional-promulga-pec-do-trabalhoescravo.html; Acesso em: 20/08/2014.

OLIVEIRA, Ariovaldo Umbelino de. A Amazônia e a nova geografia da produção da soja. São Paulo. 2006. (impresso)

OLIVEIRA, Ariovaldo Umbelino de. A Geografia Agrária e as transformações territoriais recentes no Campo brasileiro. IN: CARLOS, Ana Fani Alessandri (org.). Novos Caminhos da Geografia. 5 ed. São Paulo: Contexto, 2005 (caminhos da Geografia).

OLIVEIRA, Ariovaldo Umbelino de. A geografia das lutas no campo. 11. Ed. São Paulo: Contexto, 2002. 
OLIVEIRA, Ariovaldo Umbelino de. Modo capitalista de produção, agricultura e reforma agrária. São Paulo: Labur edições, 2007.

PAASI, Anssi. Place and region: looking through: the prism of scale. Progress in Human Geography. N. 28. V. 4, 2004. p. 536-546.

PAULA, João Antônio de. Crise econômica e reiteração do capitalismo dependente no Brasil. In: ALMEIDA, Alfredo Wagner Berno de (et al.). Capitalismo Globalizado e recursos naturais: fronteiras da acumulação no Brasil contemporâneo. Rio de Janeiro: Lamparina, 2010.

PNUD. Índice de Desenvolvimento Humano Municipal Brasileiro. - Brasília: PNUD, Ipea, FJP, 2013

PRADO JR., CAIO. História Econômica do Brasil. São Paulo, Brasiliense, 1963

RODRIGUES, Sávio José Dias. Quem não tem é escravo de quem tem: Migração camponesa e a reprodução do trabalho escravo contemporâneo / Sávio José Dias Rodrigues. Fortaleza-CE, 2016.

SAKAMOTO, Leonardo. Os acionistas da casa grande: a reinvenção capitalista do trabalho escravo no Brasil contemporâneo. In: FIGUEIRA, Ricardo Rezende; PRADO, Adonia Antunes (Orgs.) Olhares sobre a escravidão contemporânea: novas contribuições críticas. Cuiabá: EdUFMT, 2011.

SALES, Teresa. Raízes da desigualdade social na cultura política brasileira. REVISTA BRASILEIRA DE CIÊNCIAS SOCIAIS. v.9 n.25. São Paulo jun. 1994.

SANT'ANA JÚNIOR, Horácio Antunes. Florestania: a saga acreana e o Governo da Floresta. Rio de Janeiro: PPGSA/IFCS/UFRJ, 2002. (Tese de Doutorado).

SANT'ANA JÚNIOR, Horácio Antunes. Socioambientalismo e desenvolvimento na Amazônia: o caso do Acre. Revista de Politicas Publicas. São Luis - MA, v. 8, n.1, p. 61-81, 2004. 
SOARES, Fagno da Silva. Escravizados do carvão: historiando identidades e memórias em Açailândia-MA no tempo presente. Teresina: 2012. (Dissertação Programa de Pós-graduação Stricto sensu em História do Brasil-PPGHB/UFPI).

THÉRY, Hervé; MELLO, Neli Aparecida de; HATO, Julio; GIRARDI, Eduardo Paulon. Atlas do Trabalho Escravo no Brasil, São Paulo: Amigos da Terra, 2009.

TRINDADE, José Damião de Lima. Representações de trabalhadores, gatos e empregadores sobre o trabalho escravo. In: FIGUEIRA, Ricardo Rezende; PRADO, Adonia Antunes (Orgs.) Olhares sobre a escravidão contemporânea: novas contribuições críticas. Cuiabá: EdUFMT, 2011.

VELHO, Otávio Guilherme. Capitalismo Autoritário e Campesinato (um estudo comparativo a partir da fronteira em movimento). São Paulo/Rio de Janeiro: DIFEL, 1979. 